\title{
Basic C-peptidemia and Diabetic Patients Classification
}

\author{
Deh Zhou Patricia ${ }^{1,}$, , Koffi Dago Pierre ${ }^{2}$, Kouassi Joël-Brice ${ }^{3}$, Montéomo Gnaté François ${ }^{4}$, \\ Kouassi Franck², Yao Assita², Hué Adélaïde², Abodo Jacko Rhedoor ${ }^{2}$, Yapi Ahoua ${ }^{5}$, \\ Lokrou Adrien ${ }^{2}$ \\ ${ }^{1}$ Laboratory of Histology-Embryology and Cytogenetics, UFR-Medical Sciences, University Félix Houphouët-Boigny, Abidjan, Côte \\ d'Ivoire \\ ${ }^{2}$ Department of Endocrinology- Diabetology, University Teaching Hospital-Yopougon, Abidjan, Côte d'Ivoire \\ ${ }^{3}$ Laboratory of Biochemistry, UFR-Medical Sciences, University Félix Houphouët-Boigny, Abidjan, Côte d'Ivoire \\ ${ }^{4}$ Laboratory of Animal Physiology, Pharmacology - Pharmacopoeia, UFR-Nature Sciences, University Nangui-Abrogoua, Abidjan, Côte \\ d'Ivoire \\ ${ }^{5}$ Laboratory of Animal Biology, UFR-Biosciences, University Félix Houphouët-Boigny, Abidjan, Côte d'Ivoire
}

\section{Email address:}

dehzpatricia@yahoo.fr (D. Z. Patricia)

${ }^{*}$ Corresponding author

\section{To cite this article:}

Deh Zhou Patricia, Koffi Dago Pierre, Kouassi Joël-Brice, Montéomo Gnaté François, Kouassi Franck, Yao Assita, Hué Adélaïde, Abodo Jacko Rhedoor, Yapi Ahoua, Lokrou Adrien. Basic C-peptidemia and Diabetic Patients Classification. Science Journal of Clinical Medicine. Vol. 6, No. 6, 2017, pp. 116-119. doi: 10.11648/j.sjcm.20170606.14

Received: September 1, 2017; Accepted: September 30, 2017; Published: November 13, 2017

\begin{abstract}
Diabetes is a real public health problem in the world. In Africa in general and in Côte d'Ivoire in particular, the management of diabetes is complicated by socio-economic difficulties. After the diagnosis of diabetes, its typing is carried out on the basis of clinical criteria. With the discovery of many subgroups of diabetes especially in Africa, the classification of diabetes is made difficult. This difficulty may raise questions about the adequacy of the therapeutic treatment of patients. The purpose of this study was to study mainly the contribution of basal C-peptidemia in the typing of diabetic subjects. The material concerned a population of 220 diabetics who carried out their peptide $\mathrm{C}$ assay and monitored at the YopougonABIDJAN University and Hospital Center. Basal C-Peptidemia was assayed by competitive radio-immunoassay using the kit CIS -BIO Shering. The results revealed that the classification based on clinical signs was improved after the C-peptide assay. Indeed, after C-peptidemia, type 1 diabetics with low C-peptidemia $(<0.5 \mathrm{ng} / \mathrm{ml})$ and type 2 diabetics with normal Cpeptidemia $(0.5 \mathrm{ng} / \mathrm{ml}$ to $3 \mathrm{ng} / \mathrm{ml})$. In conclusion, the determination of peptide $\mathrm{C}$ appears as an undeniable tool for better classification of diabetic patients. The results of C-peptidemia would direct the practitioner towards a more adequate treatment in the patients studied.
\end{abstract}

Keywords: Diabetes, C-peptide, Classification, Type 1 Diabetes, Type 2 Diabetes, Insulin-secreting Function

\section{Introduction}

Diabetes is a major public health problem in every country in the world. It affects all social strata.

In 1998, this pathology reached 140 million people worldwide and a figure of 300 million patients is projected by 2025 [2].

Much progress has been made in recent years in the area of classification and diagnosis of diabetes by WHO experts, but there are difficulties in classifying many subgroups of diabetics, especially in Africa. This would be linked to forms peculiar to Africa which appear to be highly heterogeneous in terms of etiology and which the current criteria do not allow for grouping. To address these deficiencies, such as the inadequacy of the therapeutic choice and the difficulties of classification, the less widespread use of peptide $\mathrm{C}$ was proposed concomitantly with the usual dosages to improve the management of diabetes mellitus. C-peptide is a widely used measure of pancreatic beta cell function. It is produced in equimolar amounts to endogenous insulin but is excreted 
at a more constant rate over a longer time.

Peptide $\mathrm{C}$ is a useful measure of endogenous insulin secretion in diabetes treated with insulin. The main roles for peptide $\mathrm{C}$ testing are the discrimination of diabetes subtypes, which in turn informs the correct management and monitors interventions to preserve the function of the beta cell. The assay is carried out, for example, in patients receiving exogenous insulin (patients treated with insulin) and in diabetics with insulin antibodies [6, 19, 24]. The level of peptide $\mathrm{C}$ is a reflection of the endogenous pancreatic insulin secretion $[8,10,13,19]$.

While age of diagnosis is clearly a key variable associated with persistence of $b$-cell function over time, our data sets the stage for greater understanding of the heterogeneity of disease within the type of diabetes (1 and 2). C-peptide testing can be used to differentiate type 1 diabetes from MODY or type 2, and can also be used to monitor endogenous insulin secretion in the course of type 1 intervention trials.

The natural history of b-cell function and the presence of residual C-peptide during the first few years after diagnosis have been extensively studied; most individuals have some residual insulin secretion at the time of diagnosis and within 1-2 years after diagnosis $[7,20]$.

The aim of this study was to analyze the results of the Cpeptidemia assay of a population of 220 diabetic patients recruited at Yopougon University Hospital in order to evaluate the classification of diabetics.

\section{Material}

It is a population of 220 diabetics followed on an outpatient basis at the Endocrinology-diabetology consultation of University Hospital, Yopougon-Abidjan from 2004 to 2006.

Type 1 diabetes was considered to be children or adolescents and adults whose diabetes had started before the age of thirty years and in the absence of obesity criteria.

On the other hand, all subjects of higher age at the time of entry into diabetes were considered as type 2 diabetes.

\subsection{Method for the Determination of C-peptidemia}

Venous blood sampling is most often done at the bend of the elbow, without prior stimulation by the glucagon. The sampling tube generally contains a protease inhibitor (aprotinin). It can be stored at less than $20^{\circ} \mathrm{C}$ before dosing, within one month. C-peptidemia $(\mathrm{ng} / \mathrm{ml})$ was assayed by competitive radioimmunoassay using the CIS -BIO Shering kit in France.

\subsection{Statistical Analysis}

The correlation and Student tests allowed to calculate the correlation coefficient (r), mean and variance of the variables. The statistical analysis of the results between two groups of patients used the comparison test of the means and the table of the normal centered reduced law. The threshold (p) of 5\% was chosen as the limit of significance.

\section{Results}

Table 1. Distribution of Types of Diabetes.

\begin{tabular}{lll}
\hline Types of diabetes & Population & $\mathbf{\%}$ \\
\hline Type 1 diabetes & 11 & 5,45 \\
Type 2 diabetes & 201 & 91,30 \\
Atypical diabete & 8 & 3,7 \\
Overall & 220 & $100 \%$ \\
\hline
\end{tabular}

NB: The distribution of nosological forms was performed in the absence of the results of the basic C-peptidemia.

Table 2. Distribution of Type 1 Diabetics According to C-peptidemia.

\begin{tabular}{lll}
\hline C-peptidemia $(\mathbf{n g} / \mathbf{m l})$ & Types 1 diabetics & $\mathbf{\%}$ \\
\hline Low: $<0,5$ & 7 & 63,7 \\
Normal: 0,5 à 3 & 4 & 36,3 \\
Overall & $11(100 \%)$ & 100 \\
\hline
\end{tabular}

Note: Sample is small.

Table 3. Distribution of Type 2 Diabetics According to C-peptidemia.

\begin{tabular}{lll}
\hline C-peptidemia $(\mathbf{n g} / \mathbf{m l})$ & Types 2 diabetics & $\mathbf{\%}$ \\
\hline Low: $<0,5$ & 16 & 8 \\
Normal:0,5 à 3 & 185 & 92 \\
Overall & 201 & 100 \\
\hline
\end{tabular}

NB: The average age of type 2 diabetics with low C-peptidemia was $57 \pm 6$ years.

Table 4. Distribution of the Diabetics Presenting an Atypical Shape of the Disease According to C-peptidemia.

\begin{tabular}{lll}
\hline C-peptidemia (ng/ml) & Diabetics presenting an atypical shape & $\mathbf{\%}$ \\
\hline Low: $<0,5$ & 0 & 0 \\
Normal: 0,5 à 3 & 8 & 100 \\
Overall & 8 & 100 \\
\hline
\end{tabular}

Note: Sample is small.

\section{Discussion}

The method of evaluating insulin secretion by Cpeptidemia was adopted because of the lack of routine insulin dosing in our developing countries but also because of its invalidation in the case of insulin therapy [1]. Thus, in order to allow adequate treatment of diabetic patients, the $\mathrm{C}$ peptidemia assay has been proposed for a reliable approach to the residual insulin-secreting function of Langerhansian beta cells of the pancreas $[4,12,16]$. The mean rate of $\mathrm{C}$ peptidemia equal to $0,3 \mathrm{ng} / \mathrm{ml}$ characterizes insulindependent patients (dependent on insulin), an exclusive trait of type 1 diabetes. These results are similar to those of Sabot and Assamoi $[1,22]$. These authors observed a significantly lower level of C-peptidemia in type 1 diabetics [0,5 to 0,9 $\mathrm{ng} / \mathrm{ml}$ ] and lower than that of type 2 diabetics [0,9 to $5 \mathrm{ng} / \mathrm{ml}$. The relationship between C-peptidemia and insulin dependence could be summarized as follows: a low or collapsed insulin reserve more readily marks insulin dependence.

Given the interest of the residual insulin reserve in the 
distinction between type 1 diabetes and type 2 diabetes, an improvement in the classification of table 1 has been imposed.

In this table, the distribution of patients with type 1 and type 2 diabetics was based on etiological criteria already highlighted in the previous chapter. These criteria could take into account the level of the insulin reserve of the patients to perfect the classification of the patients; for better therapeutic follow-up, as Jones stated [9]. The aim was to identify true type 1 diabetics and true type 2 diabetics on the basis of the insulin reserve $[3,14]$. The first group had a C-peptidemia of less than or less than $0,5 \mathrm{ng} / \mathrm{ml}$; this rate was included in the standards or 0,5 to $3 \mathrm{ng} / \mathrm{ml}$ in the second group. The age of the latter group was generally above 40 years and constituted the bulk of type 2 diabetics. The increase in peptide $\mathrm{C}$ levels with age is explained by the appearance Insulin resistance or delicate assimilation of insulin in diabetics [17, 18].

Based on the above, the initial classification centered on the two clinical forms (type 1 diabetes, type 2 diabetes) could be redesigned: Type 1 (4) diabetics with a C-peptidemia of sufficient base in type 2 (Table 3 ); and include 16 type 2 diabetics of low C-peptidemia in type 1 (Table 2). That shows C-peptide alone been able to differentiate type 1 diabetes and type 2 diabetes.

The presence of residual insulin secretion as unexpectedly in type 1 diabetes [5], in which the immune-mediated destruction of pancreatic b-cells is delayed. Other studies have documented $\mathrm{C}$-peptide values in type 1 diabetes less than $0,5 \mathrm{ng} / \mathrm{ml}$ which we set in our work.

Thus, C-peptide levels are associated with diabetes type and duration of disease, specifically a C-peptide level of less than $0.2 \mathrm{ng} / \mathrm{ml}$ is associated with a diagnosis of type 1 diabetes mellitus $[11,15]$.

The potential problems with C-Peptide different values to identify the type diabetes type can be related to the types of levies. In fact, C-peptide can be measured in blood or urine, during a fasting or stimulated sample. We used capillary blood to perform our assay and set the limit of $0,5 \mathrm{ng} / \mathrm{ml}$ while authors who used urine $[11,13,15]$ set their limit at 0,2 $\mathrm{ng} / \mathrm{ml}$ to perform their classification. In all cases, it should be taken into account that the presence of large numbers of antiinsulin antibodies that bind both proinsulin and c-peptide can give a falsely high C-peptide reading. So, C-peptide estimate it is important to be aware of which method of collection they routinely process $[5,15]$.

Our study does have limitations. The population included here was recruited essentially from adult and urban. The sample in our study did not take into account patients with diabetes living in rural areas and those who do not have the economic means to pay the costs of dosage of the $\mathrm{C}$ peptidemia because this examination is not a common practice in our sub-region.

In summary, C-peptide measurement has a key role in the correct diagnosis of the type of diabetes in adults [11] and in children [20, 21]. C-peptide reflects insulin secretion, and the amount of insulin secreted reflects the metabolic needs of the body. C-peptide is removed from the peripheral circulation at a constant rate.

\section{Conclusion}

The contribution of basal C-peptidemia is undeniable for a better classification of diabetic patients in the management of diabetes. The results of the peptide $\mathrm{C}$ assay would direct the practitioner towards a more adequate treatment in the patients studied.

In particular, it provided a better understanding of the pathology of beta-Langerhans cells in type 1 diabetics in whom the blood level of this metabolite is low or zero. This makes it possible to envisage a better adjusted insulin treatment.

For type 2 diabetics studied, the determination of Cpeptidemia made it possible to distinguish true type 2 diabetics and those who becoming insulin-dependent. Taking into account the insulin reserve that actually exists in the latter.

\section{Acknowledgements}

The author is grateful to $\operatorname{Pr}$ Lokrou Adrien. (of Endocrinology and Diabetology Unit, medical-Sciences, University FHB-Abidjan) and Pr Yapi Ahoua. (of Laboratory of Animal Biology, University FHB-Abidjan) for the supervision of this work within the framework.

\section{References}

[1] Assamoi G. La C-peptidémie du diabète Noir africain: étude transversale chez 207 patients. Thèse Méd. Abidjan, 1991, 12$33 \mathrm{p}$.

[2] Awah PK. Diabète et médecine traditionnelle en Afrique. Soins de santé, Diabetes Voice, 2006; 51, 3: 24-26.

[3] Berger B, Stenstrom G, Sundkvist G. Random C-peptide in the classification of diabetes. Scand J Clin Lab Invest 2000; 60: 687-693.

[4] Besser RE, Ludvigsson J, Jones AG, McDonald TJ, Shields $\mathrm{BM}$, Knight BA et al. Urine C-peptide creatinine ratio is a noninvasive alternative to the mixed-meal tolerance test in children and adults with type 1 diabetes. Diabetes Care 2011; 34: 607-609.

[5] Davis AK, Du Bose SN, Haller MJ, Miller KM, Di Meglio LA and al. Prevalence of detectable c-peptide according to age at diagnosis and duration of type 1 diabetes. Diabetes Care 2015; 38:476-481.

[6] Ducorps M., Ndong W., Jupkwo B., Belmejdoub G., Thiolet C., Mayaudon H., Bauduceau B. Etude du diabète au Cameroun. Les difficultés de classification en Afrique Med. Trop. 1996; 56: 264-270.

[7] Greenbaum CJ, Beam CA, Boulware D and al. Type 1 Diabetes Trial Net Study Group. Fall in C-peptide during first 2 years from diagnosis: evidence of at least two distinct phases from composite Type 1 Diabetes Trial Net data. Diabetes 2012; 61:2066-2073. 
[8] Hope SV, Knight BA, Shields BM, Hattersley AT, McDonald TJ, Jones AG. Random non-fasting C-peptide: bringing robust assessment of endogenous insulin secretion to the clinic. Diabet Med. 2016; 33:1554-8.

[9] Jones AG, A. T. Hattersley. The clinical utility of C-peptide measurement in the care of patients with diabetes Diabet Med. 2013; 30, 803-817.

[10] Kuhtreiber WM, Washer SLL, Hsu E, et al. Low levels of Cpeptide have clinical significance for established type 1 diabetes. Diabet Med. 2015; 32:1346-53.

[11] Kulkarni CM, Patil S. Urinary C-peptide and urine Cpeptide/creatinine ratio (UCPCR) are possible predictors of endogenous insulin secretion in T2DM subjects-a randomized study. Int J Pharma Bio Sci. 2016; 7:443-446.

[12] Kumar S, Subhakumari KN. Role of anti-GAD, anti-IA2 antibodies and C-peptide in differentiating latent autoimmune diabetes in adults from type 2 diabetes mellitus. Int J Diabetes Dev Ctries. 2016; 36:313-9.

[13] Lachin JM, McGee P, Palmer JP, DCCT/EDIC Research Group. Impact of C-peptide preservation on metabolic and clinical outcomes in the diabetes control and complications trial. Diabetes. 2014; 63:739-48.

[14] Lee A, Morley J. Classification of type 2 diabetes by clinical response to metformin-troglitazone combination and Cpeptide criteria. Endocr Pract 1999; 5: 305-313.

[15] Leighton E, Sainsbury CAR, Jones GC. A practical review of C-peptide testing in diabetes. Diabetes Therapy, 2017, 8,(3): 475-487.

[16] Little RR, Rohlfing CL, Tennill AL, Madsen RW, Polonsky KS, Myers GL et al. Standardization of C-peptide measurements. Clin Chem 2008; 54: 1023-1026.

[17] Lokrou A. Guide de prise en charge des diabétiques.
Collection santé, Editions Universitaires de Côte d'Ivoire, $2008 ; 212$ p.

[18] 10. Lokrou A, Toutou T, Ouédraogo Y. Complications du diabète sucré en milieu hospitalier en Côte d'Ivoire. Rev Fr Endocrinol Clin, 1988; 29,3: 205-10.

[19] Ludvigsson J, Carlsson A, Forsander G, Ivarsson S, Kockum I and al. C-peptide in the classification of diabetes inchildren and adolescents. Pediatr Diabetes 2012; 13: 45-50.

[20] Ludvigsson J, Carlsson A, Deli A and al. Decline of C-peptide during the first year after diagnosis of Type 1 diabetes in children and adolescents. Diabetes Res Clin Pract 2013; 100:203-209.

[21] Palmer JP. C-peptide in the natural history of type 1 diabetes. Diabetes Metab Res Rev 2009; 25:325-328.

[22] Papoz L., Lokrou A., Delcourt C., Poton-Sanchez A.,Darrack R., Toure IA, Cuisinier raynal JC. Clinical classification of diabetes in tropical west Africa. Res. Clin. Pract. France. 1998, 3, 39: 219-27.

[23] Sabot O, Tourniaire J, Charrie A, Rebattu B, Jouve M, Ayzac $\mathrm{L}$ et al. C-peptide assays of the urine and plasma at baseline and under stimulation with glucagon in healthy subjects and diabetics). Presse Med 1990; 19: 860-863.

[24] Tsimaratos M. Physiological effect of c-peptide. Nephrolog. 2004, 25, 5: 155-161.

[25] Wang L, Lovejoy NF, Faustman DL. Persistence of prolonged C-peptide production in type 1 diabetes as measured with an ultrasensitive C-peptide assay. Diabetes Care 2012; 35: 465470 .

[26] Wiedmeyer HM, Polonsky KS, Myers GL, Little RR, Greenbaum CJ et al. International comparison of C-peptide measurements. Clin Chem. 2007; 53: 784-787. 